\title{
Activated Carbon Electrode Made From Coconut Husk Waste For Supercapacitor Application
}

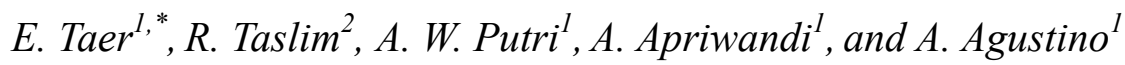 \\ ${ }^{1}$ Department of Physics, University of Riau, 28293 Simpang Baru, Riau, Indonesia \\ ${ }^{2}$ Departement of Industrial Engineering, State Islamic University of Sultan Syarif Kasim, 28293 \\ Simpang Baru, Riau, Indonesia. \\ *E-mail: erman.taer@1ecturer.unri.ac.id
}

doi: $10.20964 / 2018.12 .19$

Received: 25 June 2018 / Accepted: 16 September 2018 / Published: 5 November 2018

\begin{abstract}
Activated carbon electrode was produced from coconut husk by using a combination of physical and chemical activation methods. Potassium hydroxide $(\mathrm{KOH})$ was used as an activator during chemical activation while carbon dioxide gas $\left(\mathrm{CO}_{2}\right)$ was used as an activator during physical activation in range of $750-900{ }^{\circ} \mathrm{C}$. The physical properties of the carbon electrode was characterized by determining the density, thermogravimetry analysis, degree of microcrystallinity, surface morphology, chemical components and surface area. The crystallinity, surface morphology, and chemical content of the carbon electrode was determined by X-ray Diffraction, Scanning Electron Microscopy, and Energy Dispersive Spectroscopy. The electrochemical properties of the electrodes were reviewed by using a two-electrode system while the capacitive properties of the electrodes was determined using cyclic voltammetry. The high temperature of the physical activation resulted in the complete evaporation of volatile biomass, thereby increasing the carbon content and surface area (from $823 \mathrm{~m}^{2} \mathrm{~g}^{-1}$ to 1033.20 $\mathrm{m}^{2} \mathrm{~g}^{-1}$ ) of the electrodes. In addition, the increase in the physical activation temperature shows the presence of nanofibers in the morphology of the surface electrode. The electrochemical properties of the electrode showed excellent capacitive properties of a supercapacitor cell, with a very high specific capacitance of $184 \mathrm{~F} \mathrm{~g}^{-1}$.
\end{abstract}

Keywords: physical activation, coconut husk, activated carbon electrode, supercapacitor

\section{FULL TEXT}

(C) 2018 The Authors. Published by ESG (www.electrochemsci.org). This article is an open access article distributed under the terms and conditions of the Creative Commons Attribution license (http://creativecommons.org/licenses/by/4.0/). 